\title{
Studi Perilaku Masyarakat Bermukim di Sempadan Sungai Sa'dan Kabupaten Toraja Utara
}

\section{Study of People Behavior Living in the Sa'dan River Border, North Toraja Regency}

\author{
Julianti Paembonan ${ }^{1}$, Batara Surya ${ }^{2}$, Syafri ${ }^{3}$ \\ ${ }_{1}^{1}$ Magister Perencanaan Wilayah dan Kota Program Pascasarjana Universitas Bosowa \\ ${ }^{2}$ Program Studi Perencanaan Wilayah dan Kota, Program Pascasarjana, Universitas Bosowa \\ E-mail: bunda_adine@yahoo.com
}

Diterima: 20 Februari 2021/Disetujui 07 Juni 2021

\begin{abstract}
Abstrak. Sempadan sungai Sa'dan merupakan bagian dari daerah aliran sungai yang mengalir di Kota Rantepao. Salah satu kawasan sempadan sungai yang perlu mendapat perhatian khusus adalah sekitar sempadan sungai di wilayah Tagari dan sekitar Malango' kota Rantepao. Sungai Sa'dan ini mempunyai peran penting dalam kehidupan sehari-hari karena mempunyai fungsi ekologi, sosial dan ekonomi. Penelitian ini bertujuan untuk memberikan deskripsi Pengetahuan Lingkungan, Kebijakan Pemerintah, Kearifan Lokal dan Perilaku Masyarakat Sempadan Sungai Sa'dan Kabupaten Toraja, menganalisis Pengaruh Pengetahuan Lingkungan, Kebijakan Pemerintah, Kearifan Lokal terhadap Perilaku Masyarakat Sempadan Sungai Sa'dan Kabupaten Toraja Utara, dan mengetahui konsep pengelolaan sempadan sungai Sa'dang Kabupaten Toraja Utara. Berdasarkan tujuan penelitian yaitu untuk mengetahui pengaruh perilaku masyarakat yang bermukim di sempadan sungai Sa'dan terhadap lingkungan, maka penelitian ini merupakan penelitian yang mengacu pada Pendekatan Kuantitatif dan kualitatif, artinya penentuan sampling, perekaman data, hingga proses analisis penelitian ini menggunakan pendekatan kuantitatif. Dari hasil penelitian dan pembahasan yang dilakukan maka ditarik kesimpulan sebagai berikut, Hasil Deskriptif: Pengetahuan Lingkungan dibentuk dari kondisi eksisting dan Konsep Penataan. Hal utama yang membentuk pengetahuan lingkungan adalah kondisi eksisting. Kebijakan Pemerintah dibentuk dari beberapa indicator antara lain Organisasi, regulasi dan Implementasi Kebijakan. Hal utama yang membentuk Kebijakan Pemerintah adalah Regulasi (Peraturan). Kearifan Lokal dibentuk dari Kebiasaan masyarakat yang turun temurun, Kepercayaan masyarakat setempat dan Adanya Tanggung jawab masyarakat setempat. Hal utama yang membentuk Kearifan Lokal adalah Kebiasaan masyarakat yang turun temurun. Pengetahuan Lingkungan, Kebijakan Pemerintah, Kearifan Lokal berpengaruh terhadap Perilaku Masyarakat sempadan Sungai Sa'dan Kota Rantepao. Hal ini menunjukkan Pengetahuan Lingkungan (X1), Kebijakan Pemerintah (X2), Kearifan Lokal (X3) dapat meningkatkan Perilaku Masyarakat sempadan Sungai Sa'dan Kota Rantepao. Pentingnya masyarakat sempadan Sungai Sa'dan Kota Rantepao dalam kegiatan konservasi sempadan sungai sa'dan mengindikasikan bahwa masyarakat telah memahami mengenai konsep sempadan sungai, sehingga tanpa paksaan masyarakat megetahui batasan-batasan mengenai hal-hal yang seharusnya dilakukan dan tidak dilakukan di sempadan sungai.
\end{abstract}

Kata Kunci: Perilaku Masyarakat, Pengetahuan Lingkungan, Kebijakan Pemerintah, Kearifan Lokal

\begin{abstract}
The border of the Sa'dan river is part of the river basin that flows in the City of Rantepao. One of the river border areas that need special attention is around the riverbank in the Tagari area and around Malango', the city of Rantepao. The Sa'dan River has an important role in daily life because it has ecological, social and economic functions. This study aims to provide a description of Environmental Knowledge, Government Policy, Local Wisdom and Community Behavior of the Sa'dan River Border Community in Toraja Regency, to analyze the Effects of Environmental Knowledge, Government Policy, Local Wisdom on the Behavior of the Sa'dan River Border Community in North Toraja Regency, and to know the concept management of the Sa'dang river border, North Toraja Regency. Based on the research objective, which is to determine the effect of the behavior of the people living on the border of the Sa'dan river on the environment, this research is a research that refers to quantitative and qualitative approaches, meaning that the determination of sampling, recording data, to the analysis process of this research uses a quantitative approach. From the results of the research and discussion carried out, the following conclusions are drawn, Descriptive Results: Environmental Knowledge is formed from existing conditions and the Concept of Arrangement. The main factor that shapes environmental knowledge is the existing conditions. Government policies are formed from several indicators, including organization, regulation and policy implementation. The main thing that shapes Government Policy is Regulation (Regulation). Local wisdom is formed from hereditary habits of the community, local community beliefs and local community responsibilities. The main factor that forms local wisdom is the community's hereditary habits. Environmental Knowledge, Government Policies, Local Wisdom affect the Behavior of the People on the River Sa'dan Rantepao City. This shows that Environmental Knowledge (X1), Government Policy (X2), Local Wisdom (X3) can improve the Behavior of the People on the River Basin and the City of Rantepao. The importance of the Sa'dan River border community in Rantepao City in the sa'dan river border conservation activities indicates that the community has
\end{abstract}


understood the concept of the river border, so that without coercion the community knows the boundaries of things that should and should not be done on the riverbank.

Keywords: Community Behavior, Environmental Knowledge, Government policy, Local Culture

\section{Pendahuluan}

Semakin pesatnya perkembangan industri di Indonesia, terkadang tidak diikuti dengan kegiatan ramah lingkungan.Adanya penggunaan styrofoam, percobaan produk pada hewan, dan pembuangan limbah sembarangan adalah beberapa kegiatanyang tidak ramah lingkungan dan turut menyumbang permasalahan lingkungan, terutama pada masalah pemanasan global. Pada dewasa ini, perusahaan-perusahaan terpacu untuk meningkatkan pengetahuan dan kepedulian terhadap lingkungan hidup dengan mengembangkan berbagai program yang memberikan solusi kepada permasalahan lingkungan.

Negara memiliki tanggung jawab untuk membuat aturan berkaitan bumi, air dan tanah beserta isinya yang dapat mewujudkan cita-cita bangsa yakni kesejahteraan atau kemakmuran rakyat. Untuk itu diperlukan pembangunan yang memanfaatkan bumi, air dan tanah beserta kekayaan alamnya tersebut dengan tetap mempertahankan layaknya pembangunan tersebut untuk lingkungan. sesuai dengan Pasal 33 Ayat 3 Undang-undang Dasar Tahun 1945 menyatakan bahwa "Bumi, air dan kekayaan alam yang terkandung didalamnya dikuasai oleh Negara dan dipergunakan sebesar-besarnya kemakmuran rakyat", hal ini menjelaskan bahwa selain memiliki kewajiban dalam mensejahterakan rakyatnya negara juga memiliki hak untuk mengatur bumi, air dan tanah beserta isinya.

Penyelenggaraan penataan ruang adalah kegiatan yang meliputi pengaturan, pembinaan, pelaksanaan, dan pengawasan. Pelaksanaan penataan ruang adalah upaya pencapaian tujuan penataan ruang meliputi pelaksanaan, perencanaan tata ruang, pemanfaatan ruang, dan pengendalian pemanfaatan ruang. Undang-Undang Nomor 23 Tahun 2014 tentang Pemerintahan Daerah, maka setiap daerah diberikan kewenangan yang lebih luas dalam mengatur urusan rumah tangganya sendiri yakni kewenangan dalam menentukan kebijakan pemerintahan diberbagai bidang termasuk didalam penataan ruang, hal ini juga disebutkan didalam Undang-Undang Nomor 26 Tahun 2007 tentang Penataan Ruang pada pasal 5 ayat (3) yang mengatur penataan ruang berdasarkan wilayah administratif terdiri atas penataan ruang nasional, penataan wilayah provinsi dan penataan ruang wilayah kabupaten kota.

Pada Pasal 4 peraturan menteri pekerjaan umum dan perumahan rakyat di jelaskan bahwa sempadan sungai meliputi ruang di kiri dan kanan palung sungai di antara garis sempadan dan tepi palung sungai untuk sungai tidak bertanggul, atau di antara garis sempadan dan tepi luar kaki tanggul untuk sungai bertanggul. Garis sempadan sungai bertanggul di dalam kawasan perkotaan ditentukan paling sedikit berjarak 3 (tiga) meter dari tepi luar kaki tanggul sepanjang alur sungai, namun berbeda dengan kanal yang memiliki garis sempadan sendiri (Rahayu et al., 2021).

Dalam rangka pemanfaatan ruang dan pengawasan pemanfaatan ruang yang sesuai dengan peruntukan, pemerintah kabupaten Toraja Utara telah memberikan arahan pengendalian pemanfaatan ruang sempadan sungai. Arahan peraturan pengendalian pemanfaatan ruang di jelaskan dalam Pasal 22 Peraturan Daerah Kabupaten Toraja Utara Nomor 6 Tahun 2018 tentang pembinaan, pemanfaatan dan pengawasan sempadan sungai bahwa : "Setiap orang perorangan, Badan Hukum dan Organisasi Masyarakat dilarang menempatkan, mendirikan dan merenovasi bangunan dan/atau pagar pekarangan, baik secara keseluruhan atau sebagian dengan jarak kurang dari ketentuan sebagaimana dimaksud dalam Pasal 7, Pasal 13 dan Pasal 17 Peraturan Daerah ini”.

Sungai Sa'dan merupakan sungai besar dan panjang yang hulunya di Kecamatan Sa'dan Kabupaten Toraja Utara yang selanjutnya dalam RTRW Provinsi Sulawesi Selatan dipertegas lagi bahwa Sungai Sa'dan merupakan bagian dari Satuan Wilayah Sungai (SWS) Saddang dengan luas DAS $6.696,10 \mathrm{~km}^{2}$ yang melintasi 2 provinsi dan 5 kabupaten, yakni masing-masing Kabupaten Toraja Utara, Tana Toraja, Mamasa, Enrekang, dan Pinrang. Gangguan pada sempadan yang merupakan kawasan lindung dari sungai tersebut, adalah gangguan di sempadan seperti pemanfaatan lahan untuk permukiman dan juga tempat membuang sampah, akan menimbulkan permasalahan seperti hilangnya kawasan lindung sabuk hijau. Sabuk hijau merupakan penghijauan yang ditanami pepohonan yang ditata dan dirancang sesuai fungsi ekologinya sebagai pengendali tata air, pencegah erosi, sebagai paru-paru lingkungan, fungsi fisiknya sebagai peneduh untuk menciptakan kesejukan lingkungan, serta fungsi estetisnya untuk menciptakan keindahan dan keasrian lingkungan. Pada sabuk hijau yang terletak di daerah sempadan sungai disyaratkan tidak diperbolehkan ada bangunan (gedung) permanen, semi permanen, dan non permanen.

Pemanfaatan ruang pada kawasan sempadan sungai, umumnya mengalami kecenderungan tidak terkontrolnya persebaran bangunan pada daerah aliran sungai yang berdampak pada penurunan kualitas sungai. Selain itu masyarakat yang menempati sempadan sungai, umumnya membuang sampah dan limbah rumah tangga langsung ke badan air sungai (Syarfi et al., 2020). Padahal, sungai merupakan salah satu sumber air bersih yang penting dalam kehidupan. Manfaat sungai antara lain adalah sebagai kawasan konservasi, drainase makro kota, tempat rekreasi, pengairan, sumber air baku bagi PDAM. Akan tetapi keberadaan sungai tersebut akan sangat berbahaya jika tidak dilakukan pengendalian serta pengawasan pembangunan pada sempadan sungai dan badan sungai karena dapat menyebabkan terjadinya penyempitan badan sungai, bahkan bisa menimbulkan bahaya-bahaya lain seperti banjir, erosi, sedimentasi, terkhusus saat ini telah terjadi perubahan iklim di kota-kota besar di Indonesia (Rasyidi et al., .

Kadang permasalahan yang timbul di sempadan sungai sering berkaitan dengan pertumbuhan perumahan dan aktifitas pada perumahan di kawasan sempadan sungai, antara lain semakin bertambahnya kegiatan dengan alasan untuk pemenuhan kebutuhan hidup. Bila ditelusuri secara seksama menurunnya kualitas lingkungan di sempadan sungai tersebut dimungkinkan karena perilaku masyarakat yang berdomisili di sempadan sungai belum berperilaku baik dalam aktifitas sehari-hari di sempadan sungai Sa'dan 
di Kota Rantepao. Sehingga menjadi sebuah fenomena jika adanya aktifitas kegiatan masyarakat disempadan sungai masih menjadi persoalan yang belum terselesaikan oleh pemerintah, dan Pemerintah Kabupaten Toraja Utara seperti belum mengambil langkah konkrit dalam rangka meningkatkan kesadaran masyarakat dalam berperilaku yang benar dalam memanfaatkan, dan memelihara lingkungan di kawasan sempadan sungai Sa'dan.

Terkait hal ini kesadaran dan perilaku masyarakat yang bermukim di sekitar sempadan sungai Sa'dan di kota Rantepao terkesan karena adanya ketidak pedulian masyarakat terhadap lingkungan sebagai akibat dari belum terselesaikannya masalah pertambahan rumah-rumah yang di bangun masyarakat di sempadan sungai. Selain itu perilaku masyarakat yang kurang baik terhadap lingkungan dapat juga disebabkan karena masyarakat dalam kegiatan pelestarian lingkungan di sempadan sungai Kota Rantepao relatif masih kurang peduli terhadap kondisi lingkungan. Rendahnya perilaku lingkungan masyarakat di sempadan sungai tersebut diduga dipengaruhi oleh beberapa faktor, seperti: pengetahuan lingkungan yang rendah, sikap negatif terhadap lingkungan, rendahnya motivasi masyarakat terhadap pelestarian lingkungan serta kebijakan atau regulasi pemerintah yang tidak aspiratif mengakibatkan perilaku masyarakat dalam pengelolaan kawasan sempadan sungai juga menjadi buruk (Syafri 2018). Kondisi tersebut diperkuat oleh teori Fishen dan Ajzen (1991) dimana secara spesifik menjelaskan bahwa terdapat berbagai faktor (variabel) yang dapat mempengaruhi perilaku, yaitu: general attitudes, personality trait, values, emotions, intelegence, social, age, gender, race, etnicity, education, income, religion, information, experience, knowledge, perception, media exp, control beliefs, subjective norm, dan intention.

Sempadan sungai Sa'dan merupakan bagian dari daerah aliran sungai yang mengalir di Kota Rantepao. Salah satu kawasan sempadan sungai yang perlu mendapat perhatian khusus adalah sekitar sempadan sungai di wilayah Tagari dan sekitar Malango' kota Rantepao. Sungai Sa'dan ini mempunyai peran penting dalam kehidupan sehari-hari karena mempunyai fungsi: (1) ekologi yaitu habitat bagi organisme perairan dan daerah tangkapan air (catchment area), (2) sosial yaitu sumber air bersih dan baku masyarakat dan (3) ekonomi yaitu sumber air untuk irigasi.

Penyebab semakin tingginya kerapatan penduduk sepanjang aliran sungai Sa'dan karena adanya perkembangan pembangunan fisik (pemukiman) dan usaha sehingga menarik minat masyarakat untuk bermukim di sempadan sungai. Banyak faktor yang menunjukkan adanya perilaku buruk masyarakat terhadap sempadan sungai Sa'dan, yaitu rumah tangga yang membuang sampah ke sungai tanpa adanya pengolahan limbah, kegiatan usaha kerajinan rumah tangga, dan kegiatan usaha peternakan, serta kegiatan perdagangan disekitar sempadan sungai. Perilaku masyarakat dalam pemanfaatan kawasan sempadan sungai Sa'dan merupakan sebuah kegiatan yang sangat merugikan untuk komunitas air sungai, hal ini menimbulkan tingkat kekumuhan di bangunan sempadan sungai cenderung tingg (Marjuni et al., 2020).
Berdasarkan Undang-Undang Nomor 23 Tahun 1997 pasal 1 ayat 2, tentang pengelolaan lingkungan menyatakan, bahwa usaha pengelolaan lingkungan merupakan upaya terpadu dalam melestarikan fungsi lingkungan yang meliputi kebijakan penataan, pemanfaatan, pengembangan, pemeliharaan, pemulihan dan pengawasan lingkungan dan pasal 5 menyatakan, bahwa setiap orang mempunyai hak yang sama atas lingkungan hidup yang baik dan sehat, setiap orang berhak atas informasi lingkungan hidup yang berkaitan dengan peran pengelolaan lingkungan hidup, dan setiap orang mempunyai hak untuk berperan dalam rangka pengelolaan lingkungan hidup sesuai dengan peraturan perundangundangan yang berlaku.

Sempadan sungai Sa'dan saat ini mengalami kondisi yang cukup memprihatinkan, hal ini terkait dari beberapa aspek. Dari aspek ekologi yaitu habitat bagi organisme perairan sebab semakin berkurangnya mahluk hidup air tawar yang hidup didalamnya akibat kualitas air yang semakin menurun, dapat dilihat dari warna air sungai Sa'dan yang semakin keruh. Dari aspek sosial yaitu sebagai sumber air bersih dan baku bagi masyarakat, tetapi pada kenyataannya sangat bertolak belakang karena kualitas air yang semakin menurun baik dari warna dan kebersihan. Aspek ekonomi yaitu sebagai sumber air untuk irigasi kadang sudah berkurang, apalagi jika musim kemarau.

Kondisi lingkungan hidup dapat merubah perilaku masyarakat dan disisi lain perilaku masyarakat dapat membentuk kondisi lingkungannya, perilaku masyarakat dapat berupa obyek dan sekaligus sebagai subyek bagi lingkungannya. Ajzen mengemukakan bahwa perubahan perilaku sangat ditentukan oleh pengetahuan (knowledge), sikap (attitudes), pengaruh (self-efficacy), tempat (locus of control), dan maksud (intent). Seyogyanya untuk menciptakan Kota yang ideal (Ideal City) suatu ruang yang direncanakan sebaiknya dengan mengikuti aturan alam, karena yang dari alam itu justru merupakan sesuatu yang sudah ideal. Soerjadi mengemukakan bahwa dalam menata ruang, ada tiga upaya yang harus dijalankan secara seimbang yaitu upaya teknologi, upaya sikap/perilaku serta upaya untuk memahami dan menerima koreksi alami.

Chen (2013) menunjukkan bahwa pengetahuan lingkungan adalah serangkaian pengetahuan ekologis yang dimiliki oleh individu mengenai lingkungan. Lee (2011), menganggap bahwa pengetahuan mengenai ekologis adalah suatu pengetahuan dasar yang dimiliki oleh seorang konsumen tentang hal-hal yang bisa dilakukan untuk membantu dalam aktivitas perlindungan lingkungan yang difasilitasi dengan komitmen perilaku untuk melakukan pembelian produk hijau. Dengan semakin tinggi tingkat pengetahuan dan perhatian lingkungan yang dimiliki oleh seorang konsumen,maka semakin tinggi pula sikap ekologis yang dimiliki oleh konsumen tersebut dibandingkan dengan konsumen yang tidak memiliki pengetahuan dan perhatian terhadap lingkungan yang selanjutnya mempengaruhi perilaku ekologisnya.Ada yang beranggapan bahwa jika semakin baik pengetahuan lingkungan yang dimiliki oleh konsumen, maka konsumen akan semakin tahu tentang kualitas produk ramah lingkungan, sehingga akan meningkatkan motivasi mereka 
untuk membeli produk ramah lingkungan (Banyte et al., 2010).

Bentuk atau macam pelanggaran yang ada di sempadan Sungai Sa'dan beragam antara lain sejumlah bangunan permanen dan non permanen di bangun untuk berbagai kepentingan hunian, usaha pertukangan, peternakan dan lainnya. Hal ini menunjukan adanya fenomena perilaku masyarakat yang bermukim disempadan sungai Sa'dan yang cenderung tidak terkontrol dan sangat menghawatirkan akan menjadi sebuah pemicu terjadinya kerusakan lingkungan disempadan sungai, yang mengakibatkan terjadinya penurunan kualitas lingkungan di sempadan sungai maka perlunya pengendalian (Ariadi et al, 2020). Kondisi ini sangat memprihatinkan karena semakin banyak bangunan yang berdiri disempadan sungai Sa'dan yang cukup mengganggu, baik dari estetika lingkungan maupun secara fisik lingkungan. Seringkali oleh masyarakat sekitar menjadikan sungai Sa'dan sebagai tempat pembungan sampah, limbah manusia dan limbah ternak yang mengakibatkan semakin buruknya kualitas air sungai Sa'dan. Perilaku seperti ini yang membuat penulis ingin mengetahui secara jelas, apakah perilaku mereka terjadi karena ketidaktahuan akan pentingnya menjaga lingkungan khususnya bagian dari sempadan sungai, atau karena merupakan sebuah sikap acuh yang karena kebiasaan yang sering terjadi dan berulang karena kurang disadari dan karena tidak adanya niat untuk menjaga lingkungan tempat tinggalnya.

Berdasarkan uraian diatas inilah yang melatar belakangi sehingga penulis mencoba untuk mengkaji tentang Perilaku Masyarakat Sempadan Sungai Sa'dan Kabupaten Toraja Utara Studi Kasus Sempadan Sungai Sa'dan Kota Rantepao, yang bertujuan untuk mengetahui sejauh mana dampak akibat perilaku masyarakat di sempadan sungai Sa'dan serta menganalisis dampak perubahan yang ditimbulkan akibat perilaku masyarakat. Adapun tujuan dari penelitian ini adalah sebagai berikut: Untuk memberikan deskripsi Pengetahuan Lingkungan, Kebijakan Pemerintah, Kearifan Lokal dan Perilaku Masyarakat Sempadan Sungai Sa'dan Kabupaten Toraja Utara; Untuk Menganalisis Pengaruh Pengetahuan Lingkungan, Kebijakan Pemerintah, Kearifan Lokal terhadap Perilaku Masyarakat Sempadan Sungai Sa'dan Kabupaten Toraja Utara; dan Untuk Mengetahui konsep pengelolaan sempadan sungai Sa'dang Kabupaten Toraja Utara

\section{Metode Penelitian}

\section{a. Pendekatan Penelitian}

Penelitian ini termasuk dalam pendekatan campuran antara kuantitatif dan kualitatif. Menurut Sugiyono (2015:14) bahwa pendekatan kuantitatif merupakan penelitian yang berlandaskan pada filsafat positivisme untuk meneliti populasi atau sampel tertentu dan pengambilan sampel secara random dengan pengumpulan data menggunakan instrumen, analisis data bersifat statistik.

Menurut Sugiyono (2015:15) untuk pendekatan kualitatif adalah penelitian yang berlandaskan pada filsafat postpositivisme, digunakan pada kondisi objek yang alamiah, dan peneliti adalah sebagai instrumen kunci, pengambilan sampel sumber data dilakukan secara purposive sample, yaitu pengambilan sampel dengan cara memberikan ciri khusus yang sesuai tujuan penelitian. Adapun teknik pengumpulan data yaitu dengan trianggulasi dan analisis data bersifat induktif/kualitatif serta hasil dari penelitian kualitatif lebih menekankan makna dari pada generalisasi.. Penelitian ini mempunyai tingkatan yang tertinggi bila dibandingkan dengan penelitian deskripstif dan komparatif. Dengan penelitian ini maka akan dapat dibangun suatu teori yang dapat berfungsi untuk menjelaskan, meramalkan dan mengontrol suatu gejala.

Berdasarkan tujuan penelitian yaitu untuk mengetahui pengaruh perilaku masyarakat yang bermukim di sempadan sungai Sa'dan terhadap lingkungan, maka penelitian ini merupakan penelitian yang mengacu pada Pendekatan Kuantitatif dan kualitatif, artinya penentuan sampling, perekaman data, hingga proses analisis penelitian ini menggunakan pendekatan kuantitatif. Jika dilihat dari luas cakupan penelitian, cakupan wilayah dengan populasi, maka penelitian ini termasuk penelitian Survey dan jika dilihat dari hubungan variabel, maka penelitian ini termasuk penelitian Korelasional dimana pada penelitian ini dilakukan analisis berbagai faktor yang mempengaruhi perilaku masyarakat sempadan sungai Sa'dan dalam peningkatan kualitas lingkungan permukimannya.

\section{b. Lingkup Penelitian}

Batasan penelitian yang akan digunakan agar penelitian ini lebih terarah antara lain : Lokasi penelitian adalah Sempadan Sungai Sa'dan Kota Rantepao; Lingkup pembahasan terkait dengan studi perilaku masyarakat sempadan Sungai Sa'dan di Kota Rantepao; dan Mengetahui dan menganalisis pengaruh Pengetahuan Lingkungan, Kebijakan Pemerintah, Kearifan Lokal terhadap perilaku masyarakat sempadan sungai Sa'dan Kota Rantepao

\section{c. Variabel Penelitian}

Variabel adalah fenomena yang bervariasi dalam bentuk, kualitas, kuantitas, mutu standar, dan sebagainya. Dari definisi inilah maka variabel adalah sebuah fenomena (yang berubah-ubah) dengan demikian maka bisa jadi tidak ada satu peristiwa di alam ini yang disebut variabel, tinggal tergantung bagaimana kualitas variabelnya (Burhan Bungin, 2005).

Kerlinger, (2006) menyatakan bahwa variabel adalah konstruksi (constructs) atau sifat yang akan dipelajari. Dibagian lain Kerlinger (2006) menyatakan bahwa variabel dapat dikatakan sebagai suatu sifat yang diambil dari suatu suatu nilai yang berbeda (different values). Dengan demikian variabel itu merupakan suatu yang bervariasi (Sugiono, 2015).

Berdasarkan pengertian-pengertian di atas, maka dapat dirumuskan bahwa variabel penelitian adalah suatu atribut atau sifat atau nilai dari orang, obyek atau kegiatan yang mempunyai variasi tertentu yang ditetapkan oleh peneliti untuk dipelajari dan kemudian ditarik kesimpulannya.

Variabel dalam penelitian ini dibedakan menjadi dua macam, yaitu:

1) Variabel Independen yaitu variabel bebas yang merupakan variabel yang mempengaruhi atau menjadi sebab perubahannya atau timbulnya variabel dependen (terikat).

(X1) : Pengetahuan Lingkungan

(X2) Kebijakan Pemerintah

(X3) Kearifan Lokal 
2) Variabel Dependen yaitu variabel terikat merupakan variabel yang dipengaruhi atau yang menjadi akibat, karena adanya variabel bebas. Perilaku Masyarakat (Y)

\section{d. Populasi dan Sampel}

Populasi adalah merupakan wilayah generalisasi yang terdiri dari obyek/subyek yang memiliki kuantitas dan karakteristik tertentu yang ditetapkan oleh peneliti untuk dipelajari dan kemudian ditarik kesimpulannya. Itulah definisi populasi dalam penelitian, namun populasi juga adalah keseluruhan unit dalam atau kumpulan/kelompok ruang lingkup yang akan diteliti. Populasi dari penelitian ini adalah semua masyarakat yang bermukiman di kawasan sempadan sungai Sa'dan Kecamatan Rantepao, sebanyak kurang lebih $130 \mathrm{KK}$ atau 1.068 jiwa.

Untuk menentukan sampling penelitian berikut, peneliti menggunakan simple random sampling (sampel acak sederhana),. Sampel acak sederhana adalah teknik pengambilan sampel dimana jumlah sampel dipilih secara acak sesuai populasi. Alasan digunakannya teknik simple random sampling karena cukupp besarnya jumlah responden penelitian sehingga peneliti membatasi jumlah responden sesuai dengan kebutuhan yaitu pada Kepala Keluarga (KK) yang bermukin di Sempadan Sungai Sa'dan Kelurahan Malango Kecamatan Rantepao.

Sampel adalah bagian dari jumlah dan karakteristik yang dimiliki oleh populasi tersebut. Bila populasi besar, dan peneliti tidak mungkin mempelajari semua yang ada pada populasi, misalnya karena keterbatasan dana, tenaga dan waktu, maka peneliti dapat menggunakan sampel yang diambil dari populasi itu. Sampel yang digunakan dalam penelitian ini diambil menggunakan teknik total sampling. Sampel dalam penelitian ini adalah Kepala Keluarga (KK) yang bermukim di sepanjang sempadan sungai sa'dan pada Kelurahan Malango sebanyak 100 orang berdasarkan perhitungan dengan menggunakan rumus Slovin:

Keterangan

$$
n=\frac{N}{1+N(\alpha)^{2}}
$$

=besaran Sampe

$\mathrm{N}=$ besaran populasi

$\alpha=$ nilai kritis (batas ketelitian) yang diinginkan (Persen kelonggaran ketidaktelitian karena kesalahan penarikan sampel)

$$
n=\frac{130}{1+130(0,05)^{2}}
$$

$\mathrm{n}=\frac{130}{1+0,325}=130 / 1,325=98,11 / 100$ orang (pembulatan)

Peneliti telah melakukan pengamatan sebelumnya terdapat masyarakat yang bermukim di lokasi studi sempadan sungai sa'dan. Perngamatan yang dilakukan peneliti mendapatkan informasi berupa jumlah Kepala Keluarga (KK) sejumlah 100 orang. Karena peneliti hanya meneliti Kepala Keluarga (KK) yang bermukim di sepanjang sempadan sungai Sa'dan pada Kelurahan Malango dirasa mampu mewakili karakteristik populasi yang diinginkan

\section{e. $\quad$ Teknik Pengumpulan Data}

Pengumpulan data pada penelitian ini dilakukan melalui teknik kuisioner dan dokumentasi.

1) Kuisioner adalah suatu daftar pertanyaan yang disajikan kepada responden untuk memperoleh data yang berkaitan dengan penelitian.
2) Dokumentasi adalah perolehan data dengan jalan mengumpulkan informasi-informasi melalui dokumen-dokumen atau arsip-arsip yang berupa laporan atau catatan yang ada di Dinas Kependudukan Kabupaten Toraja Utara yang sesuai dengan permasalahan penelitian

f. Teknik Analisis Data

1) Analisis Deskriptif

Penelitian ini dengan bantuan SPSS 25 for windows. Analisis deskriptif dilakukan untuk mengetahui gambaran umum tanggapan responden tentang Pengetahuan Lingkungan, Kebijakan Pemerintah, Kearifan Lokal dan Perilaku Masyarakat. Dalam hal ini dilakukan analisis frekuensi relatif, rata-rata hitung, nilai maksimum dan minimum dari variabel, indikator maupun item-item penelitian.

\section{2) Uji Asumsi Klasik}

Untuk menilai independensi setiap variabel bebas maka perlu memenuhi asumsi-asumsi klasik agar diperoleh hasil yang tidak bias atau dengan kata lain untuk mengetahui apakah estimator-estimator pengujian tersebut bersifat BLUE (Best Linear Unbias Estimator) atau tidak. Efisien dari model analisis regresi berganda dengan metode kuadrat terkecil atau OLS (Ordinary Least Square) terhadap tiga atau lebih variabel yang dinamai (Gujarati, 1997:46).

3) Analisis Regresi Berganda

Metode ini digunakan untuk menguji pengaruh sebab akibat antara variable bebas $(\mathrm{X})$. Dalam hal ini variabel bebas tersebut adalah Pengetahuan Lingkungan $\left(\mathrm{X}_{1}\right)$, Kebijakan Pemerintah $\left(\mathrm{X}_{2}\right)$, Kearifan Lokal $\left(\mathrm{X}_{3}\right)$ terhadap variabel terikat (Y), Perilaku Masyarakat (Y). Statistik inferensial yang digunakan dalam analisis data adalah dengan menggunakan analisis regresi.

Adapun model matematis dari fungsi regresi bentuk hubungan variabel $\mathrm{X}$ dan variabel $\mathrm{Y}$ adalah sebagaimana berikut (Gujarati, 1997):

$$
\begin{array}{ll} 
& \mathrm{Y}=\alpha+\beta_{1} \mathrm{X}_{1}+\beta_{2} \mathrm{X}_{2}+\beta_{3} \mathrm{X}_{3}+\varepsilon \\
\text { Keterangan : } & \\
\alpha & =\text { Perilaku Masyarakat } \\
\beta 1, \beta 2, \beta 3 & =\text { Konstansta } \\
\mathrm{X} 1 & =\text { Koefisien Regresi } \\
\mathrm{X} 2 & =\text { Kengetahuan Lingkungan } \\
\mathrm{X} 3 & =\text { Kebijakan Pemerintah } \\
\varepsilon & =\text { Nilai Residu }
\end{array}
$$

4) Analisis Kualitatif

- Reduksi Data (Data Reduction) Perolehan data dari lapangan tentunya cukup banyak, peneliti perlu mencatat secara teliti dan rinci. Untuk itu perlu segera dilakukan analisis data melalui reduksi data. Mereduksi data yaitu merangkum, memilih hal-hal yang pokok, memfokuskan pada hal-hal yang penting, dicari tema dan polanya dan membuang yang tidak perlu.

- Penyajian Data (Data Display) Maksud dari penyajian data yaitu data akan terorganisasikan, tersusun dalam pola hubungan, sehingga akan semakin mudah dipahami. Dalam penelitian kualitatif, penyajian data bisa dilakukan dalam bentuk uraian singkat, bagan, hubungan antar kategori, dan flowchart. Yang paling sering digunakan dalam menyajikan data pada penelitian kualitatif adalah dengan teks yang bersifat naratif. Dengan menyajikan data akan memudahkan 
serta memahami apa yang terjadi dan memudahkan perencanaan kerja yang akan dilakukan selanjutnya.

- Menarik Kesimpulan dan Verifikasi (Conclusion Drawing Verification) Selanjutnya adalah penarikan kesimpulan dan verifikasi, karena kesimpulan awal yang dikemukakan masih bersifat sementara, dan akan berubah bila tidak ditemukan bukti-bukti yang kuat yang mendukung pada tahap pengumpulan data berikutnya. Tetapi apabila kesimpulan yang dikemukakan pada tahap awal didukung oleh buktibukti yang valid dan konsisten saat peneliti kembali ke lapangan mengumpulkan data, maka kesimpulan tersebut merupakan kesimpulan yang kredibel. Dalam penelitian kualitatif kesimpulan yang diharapkan adalah temuan baru yang sebelumnya belum pernah ada. Temuan tersebut dapat berupa deskripsi atau gambaran suatu obyek yang belum jelas sehingga akan menjadi jelas setelah diteliti.

\section{Hasil dan Pembahasan}

\section{Deskripsi Responden}

Responden dalam penelitian ini berjumlah 100 orang responden yang terdiri atas beberapa karakteristik. Adapun karakteristik responden berdasarkan umur, jenis kelamin, dan lama bermukim dijabarkan sebagai berikut:

Tabel 1 Karakteristik Responden Berdasarkan Umur

\begin{tabular}{cccc}
\hline No & Umur & $\begin{array}{c}\text { Jumlah } \\
\text { (orang) }\end{array}$ & Presentase (\%) \\
\hline 1 & $21-30$ tahun & 20 & 20 \\
2 & $31-40$ tahun & 12 & 12 \\
3 & $41-50$ tahun & 44 & 44 \\
4 & $51-60$ tahun & 24 & 24 \\
\hline & Jumlah & 100 & 100 \\
\hline
\end{tabular}

Mayoritas responden berusia antara 41 - 50 tahun sebanyak 44 orang (44\%). Sedangkan yang lain berusia antara 21 - 30 tahun sebanyak 20 orang (20\%), berusia antara 31 - 40 tahun sebanyak 12 orang (12\%) dan berusia 51 - 60 sebanyak 24 orang $(24 \%)$.

Tabel 2 Karakteristik Responden Berdasarkan Jenis Kelamin

\begin{tabular}{cccc}
\hline No & Jenis kelamin & $\begin{array}{c}\text { Jumlah } \\
\text { (orang) }\end{array}$ & Presentase (\%) \\
\hline 1 & Laki-laki & 85 & 85 \\
2 & Perempuan & 15 & 15 \\
\hline & Jumlah & 100 & 100 \\
\hline
\end{tabular}

Sumber : Analisa Data, 2021

Mayoritas responden berjenis kelamin laki-laki dengan jumlah 85 orang $(85 \%)$. Sedangkan sisanya berjenis kelamin perempuan dengan jumlah 15 orang (15\%).

Tabel 3 Karakteristik Responden Berdasarkan Lama Bermukim

\begin{tabular}{cccc}
\hline No & Lama Kerja & $\begin{array}{c}\text { Jumlah } \\
\text { (orang) }\end{array}$ & Presentase (\%) \\
\hline 1 & $1-10$ tahun & 12 & 12 \\
2 & $11-20$ tahun & 12 & 12 \\
3 & $21-30$ tahun & 47 & 47 \\
4 & Lebih dar 30 tahun & 29 & 29 \\
\hline & Jumlah & 100 & 100 \\
\hline
\end{tabular}

Mayoritas responden dengan lama bermukim antara 21 - 30 tahun sebanyak 47 orang (47\%). Sedangkan sisanya dengan lama bermukim $1-10$ tahun sebanyak 12 orang $(12 \%)$, antara $11-20$ tahun sebanyak 12 orang (12\%) dan lebih dari 30 tahun sebanyak 29 orang (29\%).

a. Uji Validitas

Uji validitas dimaksudkan untuk menguji apakah indikator-indikator dalam instrumen dapat mengukur variabel penelitian. Metode yang digunakan untuk uji validitas adalah metode product moment dengan kriteria yaitu bila nilai koefisien korelasi ( $\mathrm{r}$ hitung) lebih tinggi daripada $\mathrm{r}$ tabel $(\mathrm{N}=34, \alpha=0,05)$ yaitu 0,3388 , maka butir tersebut dapat dikatakan valid. 1) Hasil Uji Validitas Instrumen Pengetahuan

Tabel 4 Hasil Uji Validitas Pengetahuan Lingkungan (X1)

\begin{tabular}{llrl}
\hline Aitem & r Hitung & r Tabel & Keterangan \\
\hline $\mathrm{X}_{1.1 .1}$ & 0,401 & 0,338 & Valid \\
$\mathrm{X}_{1.1 .2}$ & 0,400 & 0,338 & Valid \\
$\mathrm{X}_{1.1 .3}$ & 0,368 & 0,338 & Valid \\
$\mathrm{X}_{1.2 .1}$ & 0,379 & 0,338 & Valid \\
$\mathrm{X}_{1.2 .2}$ & 0,594 & 0,338 & Valid \\
$\mathrm{X}_{1.2 .3}$ & 0,490 & 0,338 & Valid \\
\hline
\end{tabular}

Sumber : Analisa Data, 2021

2) Hasil Uji Validitas Instrumen Kebijakan Pemerintah

Tabel 5 Hasil Uji Validitas Kebijakan Pemerintah (X2)

\begin{tabular}{llrl}
\hline Aitem & r Hitung & r Tabel & Keterangan \\
\hline X2.1.1 & 0,507 & 0,338 & Valid \\
X2.1.2 & 0,651 & 0,338 & Valid \\
X2.1.3 & 0,748 & 0,338 & Valid \\
X2.2.1 & 0,869 & 0,338 & Valid \\
X2.2.2 & 0,716 & 0,338 & Valid \\
X2.2.3 & 0,612 & 0,338 & Valid \\
X2.3.1 & 0,690 & 0,338 & Valid \\
X2.3.2 & 0,739 & 0,338 & Valid \\
X2.3.3 & 0.748 & 0,338 & Valid \\
\hline
\end{tabular}

Sumber : Analisa Data, 2021

3) Hasil Uji Validitas Instrumen Kearifan Lokal

Tabel 6 Hasil Uji Validitas Kearifan Lokal (X3)

\begin{tabular}{llrl}
\hline Aitem & r Hitung & r Tabel & Keterangan \\
\hline X3.1.1 & 0,842 & 0,338 & Valid \\
X3.1.2 & 0,848 & 0,338 & Valid \\
X3.1.3 & 0,614 & 0,338 & Valid \\
X3.2.1 & 0,797 & 0,338 & Valid \\
X3.2.2 & 0,539 & 0,338 & Valid \\
X3.2.3 & 0,793 & 0,338 & Valid \\
X3.3.1 & 0,777 & 0,338 & Valid \\
X3.3.2 & 0,673 & 0,338 & Valid \\
X3.3.3 & 0,505 & 0,338 & Valid \\
\hline
\end{tabular}

Sumber : Analisa Data, 2021

4) Hasil Uji Validitas Instrumen Perilaku Masyarakat

Tabel 7. Hasil Uji Validitas Perilaku Masyarakat (Y)

\begin{tabular}{llrl}
\hline Aitem & r Hitung & r Tabel & Keterangan \\
\hline Y1.1.1 & 0,524 & 0,338 & Valid \\
Y1.1.2 & 0,420 & 0,338 & Valid \\
Y1.2.1 & 0,441 & 0,338 & Valid \\
Y1.2.2 & 0,405 & 0,338 & Valid \\
Y1.3.1 & 0,513 & 0,338 & Valid \\
Y1.3.2 & 0,904 & 0,338 & Valid \\
Y1.4.1 & 0,974 & 0,338 & Valid \\
Y1.4.2 & 0,736 & 0,338 & Valid \\
\hline
\end{tabular}

Sumber : Analisa Data, 2021 
b. Uji Reliabilitas

Uji reliabilitas dimaksudkan untuk menguji apakah instrument tersebut dapat dipercaya untuk mengukur variabel penelitian tersebut, metode yang digunakan untuk uji reliabilitas adalah metode croncbach's alpha dengan kriteria bila nilai alpha $\geq 0,600$ maka instrument dinyatakan reliabel

1) Hasil reliabilitas Pengetahuan Lingkungan

Tabel 8 Hasil Uji Reliabilitas Instrumen Pengetahuan Lingkungan

\section{Reliability Statistics}

\begin{tabular}{|r|r|}
\hline $\begin{array}{c}\text { Cronbach's } \\
\text { Alpha }\end{array}$ & N of Items \\
\hline .832 & 6 \\
\hline
\end{tabular}

Tabel 8 menunjukkan bahwa seluruh butir pada variabel Pengetahuan Lingkungan dinyatakan reliabel karena memiliki Alpha Cronbach lebih besar sama dengan 0,6 .

2) Hasil reliabilitas Kebijakan Pemerintah

Tabel 9 Hasil Uji Reliabilitas Instrumen Kebijakan Pemerintah

Reliability Statistics

\begin{tabular}{|c|r|}
\hline $\begin{array}{c}\text { Cronbach's } \\
\text { Alpha }\end{array}$ & N of ltems \\
\hline .749 & 9 \\
\hline
\end{tabular}

Tabel 9 menunjukkan bahwa seluruh butir pada variabel Kebijakan Pemerintah dinyatakan reliabel 3) Hasil reliabilitas Kearifan Lokal

Tabel 10 Hasil Uji Reliabilitas Instrumen Kearifan Lokal

\section{Reliability Statistics}

\begin{tabular}{|c|r|}
\hline $\begin{array}{c}\text { Cronbach's } \\
\text { Alpha }\end{array}$ & N of Items \\
\hline .618 & 9 \\
\hline
\end{tabular}

Tabel 10 menunjukkan bahwa seluruh butir pada variabel Kearifan Lokal dinyatakan reliable

4) Hasil reliabilitas Perilaku Masyarakat

Tabel 11 Hasil Uji Reliabilitas Instrumen Perilaku Masyarakat

\section{Reliability Statistics}

\begin{tabular}{|r|r|}
\hline $\begin{array}{c}\text { Cronbach's } \\
\text { Alpha }\end{array}$ & Nof ltems \\
\hline .787 & 8 \\
\hline
\end{tabular}

Tabel 11 menunjukkan bahwa seluruh butir pada variabel Perilaku Masyarakat dinyatakan reliabel

c. Uji Asumsi Klasik

Untuk menilai independensi setiap variabel bebas maka perlu memenuhi asumsi-asumsi klasik agar diperoleh hasil yang tidak bias atau dengan kata lain untuk mengetahui apakah estimator-estimator pengujian tersebut bersifat BLUE (Best Linear Unbias Estimator) atau tidak. Efisien dari model analisis regresi berganda dengan metode kuadrat terkecil atau OLS (Ordinary Least Square) terhadap tiga atau lebih variabel yang dinamai (Gujarati, 1997). Adapun asumsi-asumsi yang harus dipenuhi adalah:
1) Uji Normalitas

Tujuan uji normalitas menurut Ghozali (2007:110) adalah untuk mengetahui apakah dalam model regresi, variabel pengganggu atau residual memiliki distribusi normal. Data yang baik adalah data yang mempunyai pola seperti distribusi normal, yakni distribusi data tersebut tidak melenceng ke kiri atau ke kanan. Dasar pengambilan keputusan dalam deteksi normalitas menurut Ghozali (2007) adalah:

- Jika data menyebar di sekitar garis diagonal dan mengikuti arah garis diagonal atau grafik histogramnya maka model regresi tersebut memenuhi asumsi normalitas.

- Jika data menyebar jauh dari diagonal atau tidak mengikuti arah garis diagonal atau grafik histogram maka model regresi tersebut tidak memenuhi asumsi normalitas

$$
\text { Normal P.P Plot of Regression Standardized Residual }
$$

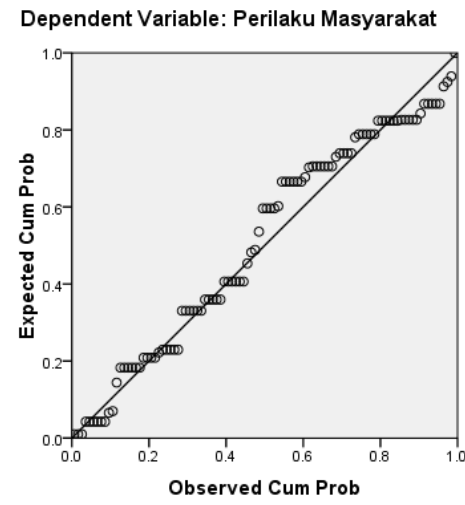

Gambar 1 Normalitas Data

Gambar 1 menunjukkan bahwa data (titik) menyebar di sekitar dan mendekati garis diagonal. Ini menunjukkan bahwa data penelitian yang mencakup variabel pengetahuan lingkungan, Kebijakan Pemerintah dan Kearifan Lokal berdistribusi normal.

2) Uji Heteroskedastisitas

Setiap observasi mempunyai reliabilitas yang sama. Gejala heteroskedastisitas ini terjadi karena terlalu bervariasinya data yang diteliti. Untuk mendeteksi gejala ini, dilakukan dengan uji korelasi ranking Spearman. Apabila koefisien korelasi ranking Spearman lebih besar dibandingkan dengan nilai kritisnya $(0,05)$, berarti ada gejala heteroskedastisitas. Sebaliknya apabila nilai korelasi Spearman lebih kecil dari nilai kritisnya, maka berarti tidak terjadi gejala heteroskedastisitas.

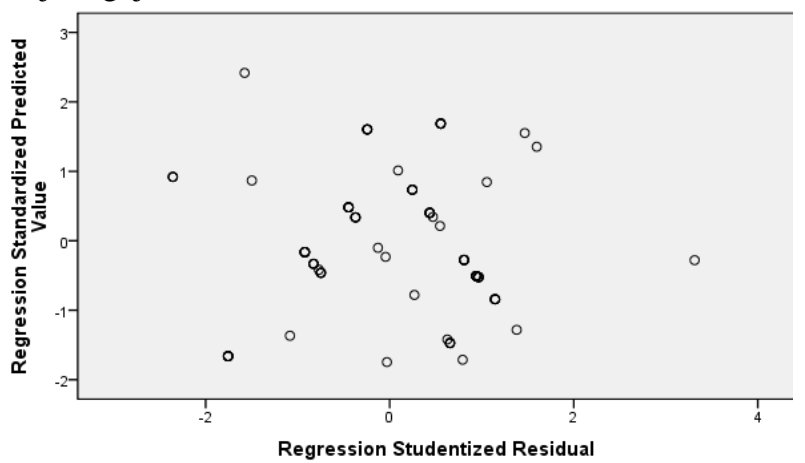

Gambar 2 Uji Heteroskedastisitas 
Berdasarkan Gambar 2, terlihat titik-titik menyebar secara acak, tidak membentuk sebuah pola tertentu yang jelas, serta tersebar baik di atas maupun di bawah angka 0 pada sumbu Y. Hal ini berarti tidak terjadi heteroskedastisitas pada model regresi.

3) Uji Multikolinearitas

Untuk melihat ada atau tidaknya gejala multikolinieritas dapat diidentifikasi dengan melihat nilai VIF (Variance Inflating Factor). Apabila nilai VIF lebih kecil dari 5 maka berarti tidak terjadi multikolinieritas antar variabel bebas (Santoso, 1999).

Suatu model bebas multikolinieritas apabila memenuhi beberapa syarat:

- Mempunyai nilai VIF (Variance Inflating Factor) lebih kecil dari 5;

- Mempunyai angka TOLERANCE mendekati 1;

- Korelasi antar variabel bebas (Independent) haruslah lemah ( di bawah 0,05)

Tabel 12. Hasil Uji Multikolinieritas

\begin{tabular}{|c|c|c|c|}
\hline \multicolumn{4}{|c|}{ Coefficients ${ }^{3}$} \\
\hline \multirow[b]{2}{*}{ Model } & & \multicolumn{2}{|c|}{ Collinearity Statistics } \\
\hline & & Tolerance & VIF \\
\hline 1 & Pengetahuan Lingkungan & .882 & 1.134 \\
\hline & Kebijakan Pemerintah & .974 & 1.027 \\
\hline & Kearifan Lokal & .886 & 1.128 \\
\hline
\end{tabular}

a. Dependent Variable: Perilaku Masyarakat

Berdasarkan hasil perhitungan VIF terlihat bahwa variabel pengetahuan lingkungan, Kebijakan Pemerintah dan Kearifan Loka mempunyai nilai $\mathrm{VIF}<5$, dengan demikian dapat disimpulkan model regresi tersebut tidak terdapat problem multikolinieritas.

d. Analisis Regresi Berganda

Metode ini digunakan untuk menguji pengaruh sebab akibat antara variable bebas (X). Dalam hal ini variabel bebas tersebut adalah Pengetahuan Lingkungan (X1), Kebijakan Pemerintah (X2), Kearifan Lokal (X3) terhadap variabel terikat (Y), Perilaku Masyarakat (Y). Statistik inferensial yang digunakan dalam analisis data adalah dengan menggunakan analisis regresi.

Adapun model matematis dari fungsi regresi bentuk hubungan variabel $\mathrm{X}$ dan variabel $\mathrm{Y}$ adalah sebagaimana berikut (Gujarati, 1997):

Model satu :

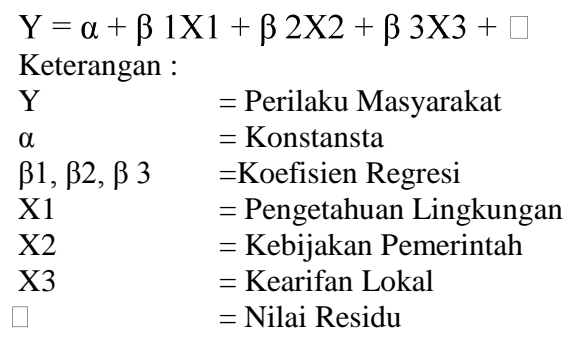

Tabel 13 Rekapitulasi Hasil Analisis Regresi Linier Berganda

\begin{tabular}{lllll}
\hline \multicolumn{1}{c}{ Variabel } & $\begin{array}{c}\text { Koefisien } \\
\text { Regresi }\end{array}$ & $\begin{array}{c}\text { T } \\
\text { hitung }\end{array}$ & Sig. & Keterangan \\
\hline Pengetahuan & 0,095 & 1,895 & 0,041 & Signifikan \\
Lingkungan & 0,130 & 3,592 & 0,001 & Signifikan \\
(X1) & 0,192 & 4,320 & 0,000 & Signifikan \\
Kebijakan & & & \\
Pemerintah (X2) & & & \\
Kearifan Lokal & & & \\
$(\mathrm{X} 3)$ & & & \\
\hline Konstanta & 24,210 & & \\
\hline
\end{tabular}

\begin{tabular}{|c|c|c|}
\hline $\mathrm{R}$ & & 0,898 \\
\hline Adusted & $\mathrm{R}$ & 0,816 \\
\hline square & & 10,097 \\
\hline F Hitung & & 0,000 \\
\hline $\begin{array}{l}\text { Sig. F } \\
\mathrm{N}\end{array}$ & & 100 \\
\hline \multicolumn{3}{|c|}{ Variabel terikat $=$ Perilaku Masyarakat $(\mathrm{Y})$} \\
\hline \multicolumn{3}{|c|}{ F tabel $=2,70(3,96, \alpha=0,05)$} \\
\hline
\end{tabular}

Berdasarkan tabel hasil rekapitulasi hasil analisis regresi berganda diatas, maka diperoleh persamaan regresi berganda sebagai berikut:

$$
\mathrm{Y}=24,210+0,095 \mathrm{X} 1+0,130 \mathrm{X} 2+0,192 \mathrm{X} 3+\square
$$

Persamaan regresi berganda diatas tersebut dijelaskan sebagai berikut:

$\alpha=24,210$ adalah konstanta. Hal ini menunjukkan bahwa saat variabel bebas Pengetahuan Lingkungan (X1), Kebijakan Pemerintah (X2), dan Kearifan Lokal (X3) bernilai 0 (nol) maka variabel terikat Perilaku Masyarakat (Y) bernilai 24,210

$\mathrm{b} 1=0,095$ adalah besarnya koefisien regresi variabel bebas Pengetahuan Lingkungan (X1). Koefisien regresi bernilai positif menunjukkan bahwa Pengetahuan Lingkungan berpengaruh positif terhadap perlaku masyarakat. Semakin baik Pengetahuan Lingkungan akan menyebabkan perlaku masyarakat mengalami peningkatkan, dengan anggapan Kebijakan Pemerintah (X2) dan Kearifan Lokal (X3) besarnya tetap. Pengaruh Pengetahuan Lingkungan (X1) terhadap perlaku masyarakat (Y) sebesar 0,095.

b2 $=0$,130adalah besarnya koefisien regresi variabel bebas Kebijakan Pemerintah (X2). Koefisien regresi bernilai positif menunjukkan bahwa Kebijakan Pemerintah berpengaruh positif terhadap perlaku masyarakat. Semakin baik Kebijakan Pemerintah akan menyebabkan perlaku masyarakat mengalami peningkatkan, dengan anggapan Pengetahuan Lingkungan (X1) dan Kearifan Lokal (X3) besarnya tetap. Pengaruh Kebijakan Pemerintah (X2) terhadap perlaku masyarakat $(\mathrm{Y})$ sebesar 0,130 .

b3 $=0,192$ adalah besarnya koefisien regresi variabel bebas Kearifan Lokal (X3). Koefisien regresi bernilai positif menunjukkan bahwa Kearifan Lokal berpengaruh positif terhadap perlaku masyarakat. Semakin baik Kearifan Lokal akan menyebabkan perlaku masyarakat mengalami peningkatkan, dengan anggapan Pengetahuan Lingkungan (X1) dan Kebijakan Pemerintah (X2) besarnya tetap. Pengaruh Kearifan Lokal (X3) terhadap perlaku masyarakat (Y) sebesar 0,192.

Nilai koefisien korelasi berganda (R) sebesar 0.898 menunjukkan adanya hubungan yang kuat antara variabel Pengetahuan Lingkungan (X1), Kebijakan Pemerintah (X2), Kearifan Lokal (X3), secara bersama-sama dengan Variabel Perilaku Masyarakat (Y).

Dari hasil perhitungan regresi linier berganda pada Tabel 13 diatas, diketahui nilai koefisien determinasi (Adjusted $R$ Square) sebesar 0,816. Koefisien determinasi ini mempunyai arti bahwa variabel Pengetahuan Lingkungan (X1), Kebijakan Pemerintah (X2) dan Kearifan Lokal (X3) secara bersama-sama mampu memberikan kontribusi terhadap variabel Perilaku Masyarakat (Y) sebesar 81,6\%, sedangkan sisanya sebesar $18,4 \%$ disebabkan oleh variabel lain yang tidak dimasukkan dalam penelitian ini.

e. Uji Hipotesis

1) Pengujian Hipotesis Pertama

- Uji F

Untuk menguji hipotesis pertama yang menyatakan bahwa Pengetahuan Lingkungan, 
Kebijakan Pemerintah dan Kearifan Lokal berpengaruh secara simultan terhadap Perilaku Masyarakat Sempadan Sungai Sa'dan Kabupaten Toraja Utara dengan menggunakan uji F. Dari hasil perhitungan analisis regresi berganda dengan SPSS diperoleh $\mathrm{F}$ hitung sebesar $10,097 \mathrm{~F}$ tabel pada $\alpha=$ $5 \%$, df1 = 3 dan df2 = 96 sebesar 2,692. Hal ini berarti $\mathrm{F}$ hitung $(10,097)>\mathrm{F}$ tabel $(2,70)$ sedangkan nilai probabilitasnya lebih kecil dari $\alpha(0,000<0,05)$, maka H0 ditolak dan H1 diterima, berarti variabel bebas Pengetahuan Lingkungan, Kebijakan Pemerintah dan Kearifan Lokal berpengaruh secara simultan dan signifikan terhadap Perilaku Masyarakat Sempadan Sungai Sa'dan Kabupaten Toraja Utara.

2) Pengujian Hipotesis Kedua

- Uji t

Untuk menguji hipotesis yang menyatakan Pengetahuan Lingkungan, Kebijakan Pemerintah dan Kearifan Lokal berpengaruh secara parsial terhadap Perilaku Masyarakat Sempadan Sungai Sa'dan Kabupaten Toraja Utara menggunakan uji t. Uji t digunakan untuk menguji apakah masing-masing variabel bebas Pengetahuan Lingkungan, Kebijakan Pemerintah dan Kearifan Lokal berpengaruh secara parsial terhadap Perilaku Masyarakat Sempadan Sungai Sa'dan Kabupaten Toraja Utara dengan membandingkan $\mathrm{t}$ hitung dengan $\mathrm{t}$ tabel. Hasil perhitungan $t$ hitung dan $t$ tabel dari masing-masing variabel bebas adalah sebagai berikut:

Tabel 14 Perbandingan $t$ hitung dan $t$ tabel

\begin{tabular}{llccl}
\hline \multicolumn{1}{c}{ Variabel } & $\begin{array}{c}\mathbf{t} \\
\text { hitung }\end{array}$ & $\begin{array}{c}\mathbf{t} \\
\text { tabel }\end{array}$ & Sig. & Keterangan \\
\hline $\begin{array}{l}\text { Pengetahuan } \\
\text { Lingkungan (X1) }\end{array}$ & 1,895 & 1,98 & 0,041 & Signifikan \\
$\begin{array}{l}\text { Kebijakan } \\
\text { Pemerintah (X2) }\end{array}$ & 3,592 & 1,98 & 0,001 & Signifikan \\
Kearifan Lokal (X3) & 4,320 & 1,98 & 0,000 & Signifikan \\
\hline Sumber : Analisa Data, 2021 & & &
\end{tabular}

Dari Tabel 14 diatas, dijelaskan sebagai berikut:

- Variabel Pengetahuan Lingkungan (X1)

Hasil analisis regresi linier berganda diperoleh nilai $\mathrm{t}$ hitung sebesar 1,895 dan $t$ tabel sebesar 1,98 sehingga $\mathrm{t}$ hitung $>\mathrm{t}$ tabel dan nilai signifikasi $(0,041)<\alpha$ $(0,05)$ jadi H0 ditolak dan H1 diterima. Dengan demikian terbukti variabel Pengetahuan Lingkungan (X1) berpengaruh terhadap Perilaku Masyarakat (Y).

- $\quad$ Variabel Kebijakan Pemerintah (X2)

Hasil analisis regresi linier berganda diperoleh nilai $t$ hitung sebesar 3,592 dan t tabel sebesar 1,70 sehingga $\mathrm{t}$ hitung $>\mathrm{t}$ tabel dan nilai signifikasi $(0,001)<\alpha$ $(0,05)$ jadi H0 ditolak dan H1 diterima. Dengan demikian terbukti variabel Kebijakan Pemerintah (X1) berpengaruh terhadap Perilaku Masyarakat (Y).

- $\quad$ Variabel Kearifan Lokal (X3)

Hasil analisis regresi linier berganda diperoleh nilai $\mathrm{t}$ hitung sebesar 4,320dan $\mathrm{t}$ tabel sebesar 1,70 sehingga $\mathrm{t}$ hitung $>\mathrm{t}$ tabel dan nilai signifikasi $(0,000)<\alpha$ $(0,05)$ jadi $\mathrm{H} 0$ ditolak dan $\mathrm{H} 1$ diterima. Dengan demikian terbukti variabel Kearifan Lokal (X1) berpengaruh terhadap Perilaku Masyarakat (Y).

3) Pengujian Hipotesis Ketiga
Untuk menguji hipotesis ketiga bahwa Kearifan Lokal berpengaruh dominan terhadap Perilaku Masyarakat Sempadan Sungai Sa'dan Kabupaten Toraja Utara dengan melihat besarnya nilai koefisien regresi yang berpengaruh signifikan terhadap Perilaku Masyarakat. Variabel bebas yang memiliki nilai koefisien regresi paling besar dan signifikan merupakan variabel yang berpengaruh dominan terhadap Perilaku Masyarakat. Berdasarkan hasil analisis uji regresi berganda pada Tabel 4,13 dapat diketahui bahwa koefisien regresi terbesar yaitu Kearifan Lokal (X3) sebesar 0,192. Hal ini berarti Kearifan Lokal (X3) merupakan variabel yang berpengaruh dominan terhadap Perilaku Masyarakat (Y). Selanjunya diikuti variabel Pengetahuan Lingkungan (X1) sebesar 0,095, dan variabel Kebijakan Pemerintah (X2) sebesar 0,130.

Pengaruh Pengetahuan Lingkungan, Kebijakan Pemerintah dan Kearifan Lokal terhadap Perilaku Masyarakat secara simultan

Nilai koefisien determinasi (Adjusted R Square) sebesar 0,885 menunjukkan bahwa Pengetahuan Lingkungan, Kebijakan Pemerintah dan Kearifan Lokal secara bersama-sama mampu memberikan kontribusi terhadap Perilaku Masyarakat sebesar 81,6\%, sedangkan sisanya sebesar $18,4 \%$ disebabkan oleh variabel lain yang tidak dimasukkan dalam penelitian ini. Dari hasil uji $\mathrm{F}$ menunjukkan bahwa Pengetahuan Lingkungan, Kebijakan Pemerintah dan Kearifan Lokal berpengaruh secara simultan terhadap Perilaku Masyarakat Sempadan Sungai Sa'dan Kabupaten Toraja Utara.

Hasil penelitian ini mendukung hasil penelitian Marfai, M. A. (2019). Dan Wibowo, H. A., Wasino, W., \& Setyowati, D. L. (2012) yang menyatakan bahwa Pengetahuan Lingkungan, Kebijakan Pemerintah dan Kearifan Lokal berpengaruh terhadap Perilaku Masyarakat secara simultan.

2. Pengaruh Pengetahuan Lingkungan, Kebijakan Pemerintah dan Kearifan Lokal terhadap Perilaku Masyarakat secara parsial

Dari hasil uji regresi diketahui variabel pengetahuan lingkungan memiliki koefisien regresi 0,095. Hal ini menunjukkan bahwa saat variabel Pengetahuan Lingkungan bernilai satu satuan maka variabel Perilaku Masyarakat bernilai 0,095. Variabel Kebijakan Pemerintah memiliki koefisien regresi sebesar 0,130 yang menunjukkan bahwa setiap saat variabel Kebijakan Pemerintah bernilai satu satuan maka Perilaku Masyarakat bernilai 0,130. Variabel Kearifan Lokal memiliki koefisien regresi sebesar 0,192 menunjukkan bahwa saat variabel Kearifan Lokal satu satuan maka Perilaku Masyarakat bernilai 0,192.

Dari hasil uji t menunjukkan bahwa Pengetahuan Lingkungan, Kebijakan Pemerintah dan Kearifan Lokal berpengaruh secara parsial terhadap Perilaku Masyarakat Sempadan Sungai Sa'dan Kabupaten Toraja Utara.

Hasil penelitian ini mendukung hasil penelitian Pasi,. (2019), Chotidjah, S. (2013), Azhar \& Alfitri, A. (2015), Sriwidodo, R. P. U. (2015) dan Rini \& Giantari (2017) yang menyatakan bahwa Pengetahuan Lingkungan berpengaruh terhadap Perilaku Masyarakat. Jika melihat hasil penelitian yang dilakukan, dapat dilihat dengan jelas bahwa Pengatahuan Tentang Pelestarian lingkungan yang tinggi akan cenderung mempengaruhi perilaku dalam 
menjaga kebersihan lingkungan. Oleh karena itu wajar apabila terdapat pengaruh yang positif dan signifikan antara Pengetahuan Tentang Pelestarian lingkungan dengan Perilaku dalam menjaga kebersihan lingkungan. Jadi dapat dinyatakan semakin tinggi Pengetahuan Tentang Pelestarian lingkungan maka semakin tinggi pula Perilaku dalam menjaga kebersihan lingkungan.

Penelitian lain Juaningsih, et al (2020) dan Sumarno, S. (2010).yang menyatakan bahwa Kebijakan Pemerintah berpengaruh terhadap Perilaku Masyarakat. Pemerintah terus mengupayakan adanya keseimbangan antara pembangunan dengan kelestarian lingkungan hidup. Salah satu upaya tersebut adalah dengan pembentukan kelembagaan. Efektivitas kelembagaan lingkungan hidup dapat dilihat dari kinerja instansi pemerintah, perangkat hukum dan peraturan perundang-undangan, serta program yang dijalankan pemerintah dalam rangka menjaga kelestarian lingkungan hidup dan melaksanakan pembangunan berkelanjutan. Saat ini, banyak kegiatan atau usaha yang berhadapan dengan masalah lingkungan karena tuntutan dari masyarakat. Masalah lingkungan juga dapat mempengaruhi kinerja suatu perusahaan dalam berbagai aktivitas bisnisnya.

Pemerintah telah melakukan berbagai cara termasuk dengan memperbaiki instrument-instrumen hukum terutama yang terkait dengan lingkungan hidup. Salah satu produk hukum terbaru yang disahkan oleh pemerintah adalah UU No 32 Tahun 2009 tentang Perlindungan dan Pengelolaan Lingkungan Hidup. Undang-undang yang berlaku sejak oktober 2009 dan tercatat dalam lembaran Negara Republik Indonesia tahun 2009 No 140 ini menggantikan peran dari UU No 23 Tahun 1997 tentang Pengelolaan Lingkungan Hidup.

Selanjutnya penelitian Setiadi, K. (2019), Novitasari, S. (2018), Affandy, S. (2017), Hilmi, M. Z. (2015).menghasilkan Kearifan Lokal berpengaruh terhadap Perilaku Masyarakat. Kearifan lokal pada tingkat individual muncul sebagai hasil proses kerja kognitif individu dalam upaya menetapkan pilihan pada nilai-nilai yang dianggap paling tepat bagi individu tersebut. Tataran kelompok memandang kearifan lokal sebagai upaya menemukan nilai-nilai bersama sebagai akibat dari polapola hubungan (setting) yang telah tersusun dalam sebuah lingkungan yang sama. Hal ini sejalan dengan salah satu karekteristik utama dari kebudayaan, yaitu kebudayaan merupakan milik bersama dan diperoleh melalui belajar dan tidak diturunkan secara biologis atau genetis (Uhi, 2016). Adanya krisis ekonomi dewasa ini, masyarakat yang hidup dengan menggantungkan alam dan mampu menjaga keseimbangan dengan lingkungannya dengan kearifan lokal yang dimiliki dan dilakukan tidak begitu merasakan adanya krisis ekonomi, atau pun tidak merasa terpukul seperti halnya masyarakat yang hidupnya sangat dipengaruhi oleh kehidupan modern. Maka dari itu kearifan lokal penting untuk dilestarikan dalam suatu masyarakat guna menjaga keseimbangan dengan lingkungannya dan sekaligus dapat melestarikan lingkungannya. Berkembangnya kearifan lokal tersebut tidak terlepas dari pengaruh berbagai faktor yang akan mempengaruhi perilaku manusia terhadap lingkungannya

Dari 13, terlihat bahwa nilai koefisien regresi dari $\mathrm{X} 1=0,170, \mathrm{X} 2=0,291$ dan $\mathrm{X} 3=0,477$. Berdasarkan data diatas dapat disimpulkan bahwa Kearifan Lokal (X3) merupakan variabel yang berpengaruh dominan terhadap
Perilaku Masyarakat (Y). Selanjunya diikuti variabel variabel Kebijakan Pemerintah (X2) dan Pengetahuan Lingkungan (X1). Dapat diartikan bahwa untuk meningkatkan Perilaku Masyarakat Sempadan Sungai Sa'dan Kabupaten Toraja Utara perlu meningkatkan Kearifan Lokal yang luhur dan ditanamkan pada diri warga sempadan sungai. Hasil ini didukung dengan penelitian Setiadi, K. (2019), Affandy, S. (2017), Hilmi (2015) menyatakan Kearifan Lokal memiliki nilai yang lebih berpengaruh terhadap perubahan Perilaku Masyarakat.

\section{Konsep Pengelolaan Sempadan Sungai Sa'dang Kabupaten Toraja Utara}

Pertumbuhan penduduk yang pesat mengakibatkan perbandingan antara jumlah penduduk dengan ketersediaan lahan tidak seimbang khususnya pertanian dan permukiman. Keadaan tersebut mendorong penduduk untuk merambah kawasan - kawasan lindung seperti kawasan sempadan sungai untuk dijadikan lahan permukiman dan lahan pertanian. Kawasan sempadan sungai yang dimanfaatkan tidak dengan kaidah - kaidah konservasi maka akan rentan terhadap erosi dan tanah longsor yang pada gilirannya akan meningkatkan muatan sedimen di sungai bagian hilir, demikian juga perambahan hutan untuk kegiatan pertanian telah meningkatkan koefisien air larian yaitu meningkatkan jumlah air hujan menjadi air larian, dan demikian meningkatkan debit sungai. Perambahan hutan juga menyebabkan hilangnya seresah dan humus yang dapat menyerap air hujan. Dalam skala besar, dampak kejadian tersebut akan mempengaruhi perilaku aliran sungai, pada musim hujan debit aliran sungai meningkat tajam sementara pada musim kemarau debit air sangat rendah, dengan demikian, resiko banjir pada musim hujan dan kekeringan pada musim kemarau meningkat (Asdak, 2010).

Menurut Kementrian Pekerjaan Umum dan Permahan Rakyat Nomor 28/PRT/M/2015 salah satu faktor penyebab terjadinya banjir yakni penggunaan sempadan sungai atau bantaran sungai yang dijadikan pemukiman warga. Perubahan penutup lahan dari penutup alami menjadi atap bangunan dan lapisan kedap air yang tanpa upaya antisipasi telah mengakibatkan semakin berkurangnya infiltrasi air hujan ke dalam tanah sehingga mengakibatkan membesarnya aliran air di permukaan tanah yang menimbulkan banjir. Hilangnya sempadan sungai juga mengakibatkan terjadinya peningkatan gerusan tebing sungai yang dapat mengancam bangunan atau fasilitas umum lain karena tergerus arus sungai.

Menurut Peraturan Menteri Pekerjaan Umum dan Perumahan Rakyat Nomor 28/PRT/M/2015 apabila sempadan sungai telah telanjur digunakan untuk fasilitas kota, bangunan gedung, jalan, atau fasilitas umum lainnya, menteri, gubernur, bupati dan/atau walikota sesuai kewenangannya dapat menetapkan peruntukan yang telah ada tersebut sebagai tetap tak akan diubah dikarenakan alasan historis atau alasan lain yang memberi manfaat lebih besar bagi kepentingan umum maka tidak akan dirubah dan justru dipertahankan sepanjang tidak ditemukan alasan yang lebih penting dari kemanfaatannya saat ini. Dalam hal lahan sempadan yang telanjur dimiliki oleh masyarakat, peruntukannya secara bertahap harus dikembalikan sebagai sempadan sungai. Sepanjang hak milik atas lahan tersebut sah kepemilikannya tetap diakui, namun pemilik lahan wajib mematuhi peruntukan lahan tersebut sebagai 
sempadan sungai dan tidak dibenarkan menggunakan untuk peruntukan lain.

Bangunan-bangunan yang telah telanjur berdiri di sempadan sungai dinyatakan statusnya sebagai status quo, artinya tidak boleh diubah, ditambah, dan diperbaiki. Izin membangun yang baru tidak akan dikeluarkan lagi. Memulihkan kembali kondisi sempadan sungai merupakan kegiatan kunci untuk memperbaiki dan menjaga fungsi sungai. Banyak manfaat yang dapat didapat dari membaiknya kembali fungsi sempadan sungai diataranya terjadi keseimbangan ekosistem sempadan sungai serta terpeliharanya daerah resapan air sehingga peluang terjadinya banjir dan kekeringan dapat dihindari. Untuk keberlangsungan jangka panjang maka sempadan sungai perlu dikendalikan agar tercapainya suatu kondisi yang harmonis dan berkelanjutan antara fungsi sungai dan kehidupan manusia. Salah satu upaya untuk mengendalikan kondisi sempadan sungai yakni dengan melakukan konservasi.

Strategi dan upaya konservasi di kawasan sempadan sungai dapat dilkukan dengan penanaman vegetasi, Menurut penelitian Mentari dkk (2018) jenis bambu Gigantochloa atter dan Bambusa vulgaris mempunyai sistem perakaran rimpang yang sangat rapat, rumpun juga sangat rapat dan bentuk kanopi yang membulat. Kedua jenis bambu ini direkomendasikan untuk dijadikan tumbuhan konservasi tanah dan air di sempadan sungai.

Kegiatan konservasi tidak akan berjalan lancar tanpa adanya keikutsertaan dan kontribusi dari masyarakat Masyarakat sempadan Sungai Sa'dan Kota Rantepao. Kawasan memiliki fungsi utama yakni sebagai kawasan lindung dan kawasan budidaya, kawasan lindung memiliki fungsi untuk melindungi kelesetarian lingkungan hidup baik di kawasan itu sendiri maupun di luar kawasan sedangkan kawasan budidaya memiliki fungsi untuk kawasan untuk dibudidayakan. Kawasan sempadan sungai berfungsi sebagai kawasan lindung, kawasan lindung maksudnya sempadan sungai sebagai pelindung ekosistem perairan (sungai) yang seharusnya didominasi oleh tumbuhan sepanjang sisi kiri dan kanan sungai. Dengan terpeliharanya sempadan sungai maka sempadan sungai dapat menjadi "tameng" yang melindungi sungai agar fungsi sungai dapat terus dimanfaat dalam jangka waktu yang panjang dan berkelanjutan. Diharapkan konsep spasial tersebut dapat mengedukasi dan memberikan pemahaman kepada masyarakat mengenai batas sempadan sungai, fungsi dan arti penting sempadan sungai bagi kelestarian lingkungan yakni melindungi kelesetarian lingkungan hidup.

Semakin disadari bahwa keberhasilan pengelolaan sempadan sungai berbasis konservasi sangat bergantung pada partisipasi masyarakat. Dengan ikut serta masyarakat dalam kegiatan konservasi maka hal tersebut mengindikasikan bahwa masyarakat telah mengerti dan paham mengenai konsep sempadan sungai, sehingga tanpa paksaan masyarakat megetahui batasan-batasan mengenai hal-hal yang seharusnya dilakukan dan tidak dilakukan di sempadan sungai. Dalam rangka pengamana terhadap daerah sekitarnya, maka perlu menetapkan lebar atau wilayah sempadan sungai, sebagai penyangga kelestarian fungsi sungai. Sehingga kelestarian sungai, berupa kelestarian sumber daya air yang terkandung di dalamnya serta sistem hidrologinya dapat terjaga dengan baik.

Selain itu, penetapan lebar sempadan sungai merupakan wujud perlindungan pemerintah kepada masyarakat, yaitu perlindungan terhadap daya rusak air. Misalnya ancaman terjadinya bencana banjir. Dengan kata lain, sempadan sungai dapat dikatakan juga, sebagai kawasan rawan bencana, yang sangat berbahaya bagi masyarakat apabila dimanfaatkan sebagai kawasan pemukiman, pedagangan, serta peruntukan budidaya lainnya demi pembangunan dan pendapatan asli daerah. Pengaturan terhadap perlindungan sempadan sungai diatur dalam Permen Pekerjaan Umum dan Perumahan Rakyat No 28-2015 Penetapan Garis Sempadan Sungai Dan Garis Sempadan Danau (PermenPUPR 28 2015). Peraturan tersebut mencabut berlakunya Peraturan Menteri Pekerjaan Umum No. 63 Tahun 1993 tentang Garis Sempadan Sungai, yang sebelumnya mengatur tentang perlindungan garis sempadan sungai.

Menurut Peraturan Menteri Pekerjaan Umum Dan Perumahan Rakyat Republik Indonesia Nomor 28/Prt/M/2015 tentang Penetapan Garis Sempadan Sungai Dan Garis Sempadan Danau (PermenPUPR 28 2015), pengertian garis sempadan sungai adalah garis maya di kiri dan kanan palung sungai yang ditetapkan sebagai batas perlindungan sungai.

Berdasarkan hasil dari penelitian, Sungai Sa'dan masih dianggap oleh beberapa masyarakat sebagai saluran aliran pembuangan air, baik air hujan dan air limbah. Masih kurangnya kesadaran bahwa sungai merupakan elemen penting di dalam kawasan pemukiman yang berfungsi selain sebagai kesatuan sistem drainase juga bermanfaat sosial sebagai lokasi ruang terbuka, penyeimbang ekosistem, bahkan sumber air bersih. Kondisi ini juga disebabkan dari tingkat pendidikan dan pengetahuan yang masih belum mencapai standar dan faktro ekonomi yang masih rendah. Faktor-faktor yang dapat mendorong masyarakat untuk berperilaku pro-lingkungan terhadap sungai juga masih kurang efektif. Regulasi yang ada masih berupa formalitas saja, lemahnya dukungan dana untuk masyarakat mengelola sungai secara mandiri, dan masih kurangnya penyuluhan atau sosialisasi tentang cara-cara mengelola sungai menjadi salah satu penyebab juga masih rendahnya perilaku pro-lingkungan sungai.

Rekomendasi dari hasil penelitian ini dapat diberikan kepada 3 pihak yaitu pemerintah, masyarakat, dan peneliti lanjutan.Bagi pemerintah, sebaiknya perlu memberikan perhatian lebih pada edukasi masyarakat dan penataan kawasan yang mempertimbangkan aspek dari hasil analisis gap penilaian masyarakat. Dengan begitu, diharapkan restorasi sungai nantinya tidak berseberangan dengan kepentingan masyarakat. Bagi masyarakat sendiri, perlu meningkatkan partisipasi dalam penataan kawasan semisal dengan membuat kampung wisata sungai mandiri. Sedangkan untuk peneliti lanjutan, penelitian ini dapat dikembangkan lagi seperti penelitian tentang peluang pengembangan kampung wisata sungai Sa'dan sebagai pendongkrak ekonomi masyarakat sekitar. 


\section{Kesimpulan dan Saran}

Hasil penelitian dapat disimpulkan bahwa pengetahuan Lingkungan dibentuk dari kondisi eksisting dan Konsep Penataan. Hal utama yang membentuk pengetahuan lingkungan adalah kondisi eksisting. Kebijakan Pemerintah dibentuk dari beberapa indikator antara lain Organisasi, regulasi dan Implementasi Kebijakan. Hal utama yang membentuk Kebijakan Pemerintah adalah Regulasi (Peraturan). Kearifan Lokal dibentuk dari Kebiasaan masyarakat yang turun temurun, Kepercayaan masyarakat setempat dan Adanya Tanggung jawab masyarakat setempat. Hal utama yang membentuk Kearifan Lokal adalah Kebiasaan masyarakat yang turun temurun. Pentingnya masyarakat sempadan Sungai Sa'dan melakukan konservasi sempadan sungai Sa'dan mengindikasikan bahwa masyarakat telah mengerti dan memahami mengenai konsep sempadan sungai, sehingga tanpa paksaan masyarakat mengetahui batasan mengenai hal yang seharusnya dilakukan dan tidak dilakukan di sempadan sungai serta berfokus pada perilaku menjaga kebersihan lingkungan sempadan sungai demi kehidupan masyarakat yang lebih baik.

\section{Daftar Pustaka}

Affandy, S. (2017). Penanaman Nilai-Nilai Kearifan Lokal dalam Meningkatkan Perilaku Keberagamaan Peserta Didik. Atthulab: Islamic Religion Teaching and Learning Journal, 2(2), 201-225.

Ajzen, I. 1991. The of Planned Behavior. Organization Behavior and Human Decision Processes.

Abil, A., Latief, R., \& Yahya, I. (2020). Strategi Pengendalian Perkembangan Permukiman Disepanjang Sungai Tallo Kelurahan Rapokalling Kecamatan Tallo Kota Makassar. Journal of Urban Planning Studies, 1(1), 098-104. Diambil dari https://ejournalfakultasteknikunibos.id/index.php/jups/ article/view/27

Asdak, C. (2010). Hidologi dan Pengelolaan Daerah Aliran Sungai. Yogyakarta: Gadjah Mada University Press.

Azhar, A., Basyir, M. D., \& Alfitri, A. (2015). Hubungan pengetahuan dan etika lingkungan dengan sikap dan perilaku menjaga kelestarian lingkungan. Jurnal Ilmu Lingkungan, 13(1), 36-41.

Banyte, J., Lina B., and Agne G. 2010. Investigation of Green Consumer Profile: A Case of Lithuanian Market of Eco-Friendly Food Products. Economics and Management. pp. 374-383.

Bungin, Burhan. 2005. Metode Penelitian Kuantitatif. Jakarta: Prenadamedia.

Chen, F. (2013). The intention and determining factors for airline passengers , participation in carbon offset schemes. Journal of Air Transport Management, 29, $17-22$.

Chotidjah, S. (2013). Pengetahuan tentang rokok, pusat kendali kesehatan eksternal dan perilaku merokok. Hubs-Asia, 10(1).

Ghozali, Imam, 2007, Aplikasi Analisis Multivariate Dengan Program SPSS, Universitas Diponogoro, Semarang

Gujarati, Damodar. 1997. Ekonometrika Dasar. Terjemahan Oleh Zumarno zain. Jakarta : Erlangga
Hilmi, M. Z. (2015). Nilai-nilai kearifan lokal dalam perilaku sosial anak-anak remaja di desa sepit kecamatan keruak kabupaten lombok timur. Journal of Educational Social Studies, 4(1).

Juaningsih, I. N., Consuello, Y., Tarmidzi, A., \& NurIrfan, D. (2020). Optimalisasi Kebijakan Pemerintah dalam penanganan Covid-19 terhadap Masyarakat Indonesia. SALAM: Jurnal Sosial dan Budaya Syar-i, 7(6), 509. 518

Kerlinger. (2006). Asas-Asas Penelitian Behavioral. Yogyakarta: Gadjah Mada University Press.

Kollmuss, A. dan Agyeman, J. 2002. Mind The Gap: why do people act environmentally and what are the barriers to pro-environmental behaviour? The Journal of EnvironmentalEducationResearch, vol.8, No.3.

Lee, K. 2011, The Green Purchase Behavior of Hong Kong Young Consumers: The Role of Peer Influence, Local Environmental Involvement, and Concrete Environmental Knowledge. Journal of International Consumer Marketing, 23, pp: 21-44.

Marjuni, S. N., Syafri, S., \& Rahman, R. (2021). Analisis Peningkatan Kualitas Permukiman Kumuh Kelurahan Tallo Kecamatan Tallo Kota Makassar. Journal of Urban Planning Studies, 1(2), 105-113. https://doi.org/10.35965/jups.v1i2.22

Mentari, M., Mulyaningsih, T., \& Aryanti, E. (2018). Identifikasi Bambu di Sub Daerah Aliran Sungai Kedome Lombok Timur dan Alternatif Manfaat Untuk Konservasi Sempadan Sungai. , 2 Jurnal Penelitian Pengelolaan Daerah Aliran Sungai. 2(2), 111-112.

Novitasari, S. (2018, February). Pengaruh Kearifan Lokal Terhadap Perilaku Tokoh Utama Dalam Novel Baduy Karya Rani Ramdayani. In Prosiding Seminar Nasional Bahasa dan Sastra Indonesia (SENASBASA) (Vol. 2, No. 1).

Pasi, I. R. (2019). Pengaruh Pengetahuan Dan Sikap Terhadap Perilaku Masyarakat Pada Bank Syariah. Jurnal Al-Qasd Islamic Economic Alternative, 1(2), 189-201.

Peraturan Menteri Pekerjaan Umum Dan Perumahan Rakyat Nomor 28/PRT/M/2015 Tentang Penetapan Garis Sempadan Sungai Dan Garis Sempadan Danau. 20 Mei 2015.

Indri Rahayu, R., Latief, R., \& Jufriadi, J. (2021). Strategi Aktifitas Pedagang Terhadap Pencemaran Kanal yang Berlokasi di Kanal Panampu Pasar Terong Kota Makassar. Journal of Urban Planning Studies, 1(2), 165-173.

Rasyidi, E. S., Sandi, R., \& Buraerah, M. F. (2020). Monitoring Perubahan Suhu Ibu Kota Negara Tahun 1993-2019 Menggunakan Citra Satelit Landsat (Studi Kasus: Jakarta, Singapura, Kuala Lumpur Dan Bangkok). Ecosystem, 20(1), 50-58.

Rini, A. S., Sukaatmadja, I. P. G., \& Giantari, I. G. A. K. (2017). Pengaruh pengetahuan lingkungan dan kepedulian lingkungan terhadap sikap dan niat beli produk hijau "The Body Shop" di Kota Denpasar. EJurnal Ekonomi dan Bisnis Universitas Udayana, 6(1), 137-166.

Santoso, Singgih. (1999). SPSS: Mengolah Data Statistik Secara Profesional Versi 7.5. Jakarta: Elex Media Komputindo 
Setiadi, K. (2019). Pengaruh Kearifan Lokal dan Kecerdasan Spiritual terhadap Perilaku Peserta Didik. Jurnal Ilmiah AL-Jauhari: Jurnal Studi Islam dan Interdisipliner, 4(1), 126-151

Sriwidodo, R. P. U. (2015). Pengaruh pengetahuan keuangan dan pengalaman keuangan terhadap perilaku perencanaan investasi dengan self control sebagai variabel moderating. Jurnal Ekonomi dan Kewirausahaan, 15(1).

Sugiyono (2015). Metode Penelitian Kombinasi (Mix Methods). Bandung: Alfabeta.

Sumarno, S. (2010). Model optimalisasi implementasi kebijakan pemerintah perihal peringatan bahaya merokok terhadap perilaku konsumen rokok (perokok) dan biaya sosial: laporan penelitian hibah bersaing. Universitas Islam Sultan Agung.

Syafri, S., Surya, B., Ridwan, R., Bahri, S., Rasyidi, E. S., \& Sudarman, S. (2020). Water Quality Pollution Control and Watershed Management Based on Community Participation in Maros City, South Sulawesi, Indonesia. Sustainability, 12(24), 10260. 